\title{
Protracted severe COVID-19 pneumonia following rituximab treatment: caution needed
}

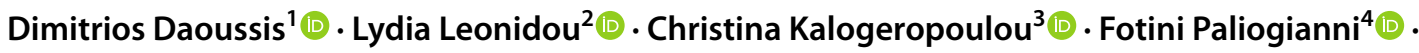 \\ Argyrios Tzouvelekis ${ }^{5}$
}

Received: 9 June 2021 / Accepted: 7 August 2021 / Published online: 19 August 2021

(c) The Author(s), under exclusive licence to Springer-Verlag GmbH Germany, part of Springer Nature 2021

\begin{abstract}
The outcomes of COVID-19 in patients treated with biologic agents are a subject of intense investigation. Recent data indicated that patients under rituximab (RTX) may carry an increased risk of serious disease. We performed an electronic search in Medline and Scopus using the keywords rituximab and COVID-19. We present a rare case of severe, protracted COVID-19 pneumonia in a patient with mixed connective tissue disease (MCTD) who was infected a few days following RTX treatment. In a relevant literature search, we identified 18 cases of patients with rheumatic diseases (6 RA, 8 ANCA vasculitis, 3 systemic sclerosis and 1 polymyositis) treated with RTX who experienced an atypical and/or prolonged course of COVID-19 pneumonia with no evidence of cytokine storm. Our case indicates that RTX may unfavorably affect outcomes following SARS-CoV-2 infection. B cell depletion may dampen the humoral response against the virus; we may hypothesize that B cell-depleted patients may be protected from cytokine storm but on the other hand may have difficulties in virus clearance leading to a protracted course. Taking into account that COVID-19 vaccines are available we may consider delaying RTX infusions at least in patients without life threatening disease, until vaccination is completed.
\end{abstract}

Keywords Rituximab · COVID-19 · SARS-Cov-2

\section{Introduction}

The recent SARS-CoV-2 pandemic has caused enormous difficulties in the routine care and management of patients with immune-mediated diseases. One of the main concerns from the beginning of the pandemic was whether immunosuppressed patients, such as patients with systemic rheumatic diseases, are more prone to develop severe disease

Dimitrios Daoussis

jimdaoussis@hotmail.com

1 Division of Rheumatology, Department of Internal Medicine, Patras University Hospital, University of Patras Medical School, Rion, 26504 Patras, Greece

2 Department of Infectious Diseases, Patras University Hospital, University of Patras Medical School, Patras, Greece

3 Department of Radiology, Patras University Hospital, University of Patras Medical School, Patras, Greece

4 Department of Microbiology, Patras University Hospital, University of Patras Medical School, Patras, Greece

5 Department of Pneumonology, Patras University Hospital, University of Patras Medical School, Patras, Greece following exposure to SARS-CoV-2. The outcomes of COVID-19 in patients treated with biologic agents is a subject of intense investigation and evidence is accumulating rapidly. Data from the COVID-19 Global Rheumatology Alliance, among other, indicated that patients under RTX may carry an increased risk of serious disease [1, 2]; this was confirmed recently in several registries [3,4] fueling concerns regarding the use of B cell depleting agents during the pandemic, especially in patients not yet vaccinated against COVID-19. Herein, we present a rare case of severe, protracted COVID-19 pneumonia in a patient with MCTD who was infected a few days following RTX treatment with a fatal outcome. Moreover, we performed a focused minireview in the literature to identify similar cases of prolonged COVID-19 in patients exposed to RTX. 


\section{Results}

\section{Case presentation}

A 76-year-old Caucasian female was diagnosed with mixed connective tissue disease in early 2018 based on peripheral arthritis, Raynaud's, esophageal dysmotility, myositis and positive anti-RNP [5]. She was initially treated with steroids and methotrexate (MTX) with partial response and on July 2018 Rituximab (RTX) was added leading to disease remission. RTX infusions were repeated every 6 months in addition to MTX and $4 \mathrm{mg}$ of methylprednisolone. MTX was discontinued in late 2019 due to hepatotoxicity and the patient remained on RTX monotherapy plus low dose steroids. On January 20, the patient was seen during an appointment in the Rheumatology Department of our institution. She was asymptomatic and received 1 gr of RTX, as scheduled. A few days later, her husband developed flu-like symptoms and was tested positive for SARS-CoV-2. On February 2, the patient with all her family members living in the same house were screened for SARS-CoV-2 (RT-PCR, nasopharyngeal swab) and were all tested positive. The patient was initially asymptomatic but soon developed low-grade fever and fatigue. Gradually she got worse with high-grade fever and cough. On February 12 she was hospitalized in a regional hospital alongside her husband who subsequently died due to COVID-19 respiratory failure. On admission her oxygen saturation was $95 \%$ on ambient air, yet, a chest CT revealed ground-glass lesions. She was treated with remdesivir, dexamethasone and low molecular weight heparin according to standard protocol; she gradually improved and was discharged to domestic quarantine on February 22. A few days following her discharge the patient started feeling unwell and reported low-grade fever. Within the following days, the patient deteriorated with high-grade fever and dry cough and was referred for admission to our hospital on March 10. On admission, she had a positive RT-PCR SARS-CoV-2 test. Her oxygen saturation was $94 \%$ and her blood tests revealed a mild leukopenia (4500), lymphopenia (630), a twofold elevation of CRP, a ferritin level of $117 \mathrm{ng} / \mathrm{ml}$ whereas antibodies against SARS-CoV-2 were undetectable. Her chest CT showed

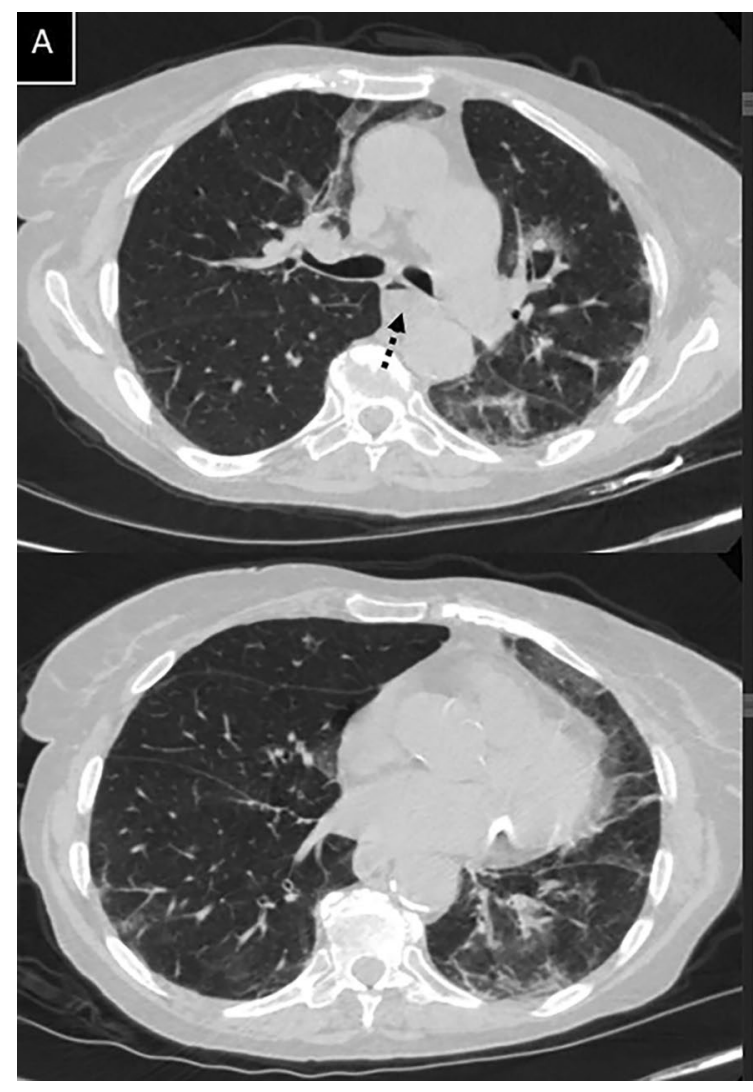

Fig. 1 CT scans at the levels of the pulmonary artery and lower pulmonary vein. Extensive ground glass and crazy paving pattern with areas of consolidations [black arrows], more prominent at the right upper and both lower lobes in $(\mathbf{B})$, indicating a prolonged evolution of

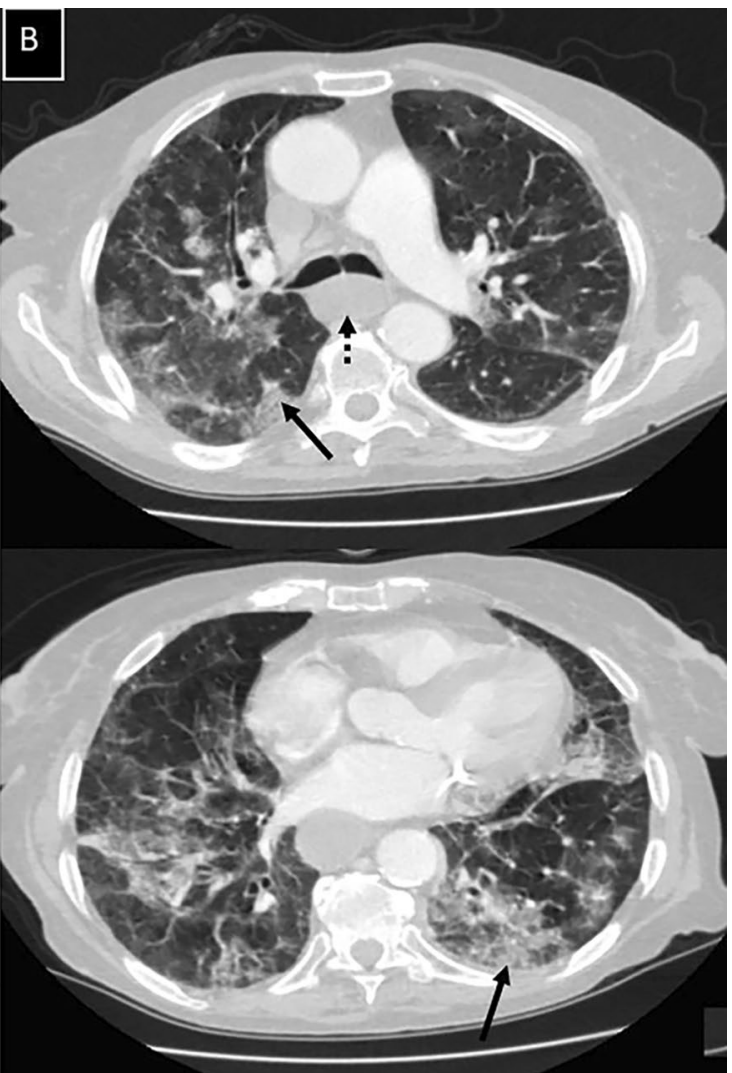

Covid 19 pneumonia. Disease progression of a mild category [severity index 6] at the initial scan (A), to a moderate category [severity index 12]. There is also marked esophageal dilatation [dotted arrow] due to the underlying rheumatic disease 
typical features of COVID-19 pneumonia (Fig. 1A). The case of SARS-CoV-2 reactivation was considered taking into account that blood cultures and an extensive workout for bacterial, fungal, parasitic and mycobacterial infections was negative. The patient was treated with broad spectrum antibiotics plus remdesivir/dexamethasone. She became afebrile and steadily improved; she was discharged on March 22 following 2 negative RT-PCR tests for SARS-CoV-2. A few days following her discharge she reported malaise and low-grade fever. The patient progressively deteriorated with high-grade fever and dyspnea and was readmitted on April 7. On admission, she was again tested positive for SARS-CoV-2 by RT-PCR whereas antibodies were once more undetectable. She presented with respiratory failure $(\mathrm{pO} 2 / \mathrm{FiO} 2=223)$, leukopenia $(3500)$ with striking lymphopenia (200), a fivefold elevation of CRP, a threefold elevation of D-Dimers, a ferritin level of $924 \mathrm{mg} / \mathrm{dl}$ whereas immunoglobulin levels were low (IgG 323, IgM 7 and $\operatorname{IgA} 59, \mathrm{mg} / \mathrm{dl}$ ). Her chest CT was markedly worse (Fig. 1B). She was treated with intravenous immunoglobulin $(2 \mathrm{mg} / \mathrm{kg}$ in total divided into 5 consecutive days), dexamethasone, broad-spectrum antibiotics and nasal high flow oxygen therapy. Extensive workup for superimposed infections was negative. The patient gradually got worse and subsequently underwent mechanical ventilation on April 29. On that day, RT-PCR for SARSCoV2 from both nasopharyngeal swabs and bronchial secretions were positive indicating a high viral load. The patient finally died on May 6 due to multi-organ failure. A timeline of the disease course is presented in Fig. 2.

\section{Literature review}

We performed an electronic search in Medline by using the keywords rituximab and COVID-19. The search (last accessed July 29) revealed 203 results. An additional search was also performed in Scopus. Our aim was to identify cases with similar characteristics with our own case: (i) carrying a diagnosis of systemic rheumatic disease, (ii) having received RTX either as monotherapy or combined with disease-modifying antirheumatic drugs in the last year prior to SARSCoV-2 exposure and (iii) exhibit an atypicaland/orprotracted course. Patients with non rheumatic, immune-based diseases such as multiple sclerosis were excluded. We focused on case reports and case series where full clinical data for each individual patient were presented. Studies reporting large datasets from registries where individual data were not shown, were excluded.

We identified 18 cases of patients with rheumatic diseases (6 RA, 8 ANCA vasculitis, 3 Systemic sclerosis and 1 polymyositis) treated with RTX who experienced an atypical, prolonged course [6-19]. By reviewing these cases we found that most had a similar protracted course with no evidence of cytokine storm (details for each case are presented in Table 1). In many cases anti-SARS-CoV2 antibodies were negative and immunoglobulin levels were low. From these limited data, it appears that IVIG and convalescent plasma on top of standard treatment may have a favorable effect on outcome. Our case is unique, however, in 2 features. The first one is the extended period of more than 3 months and the second one is that our patient was infected less than 2 weeks from RTX infusion something that might have contributed to the fatal outcome.

\begin{tabular}{|l|l|l|l|l|l|l|l|l|l|}
\hline Treatment & RTX1 gr & & $\begin{array}{l}\text { Remdesivir } \\
\text { Dexametha } \\
\text { sone }\end{array}$ & $\begin{array}{l}\text { Remdesivir } \\
\text { Dexametha } \\
\text { sone }\end{array}$ & $\begin{array}{l}\text { IVIG } \\
\text { Dexametha } \\
\text { sone }\end{array}$ & & \\
\hline
\end{tabular}

\begin{tabular}{|c|c|c|c|c|c|c|c|c|c|}
\hline Symptoms & 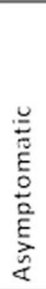 & 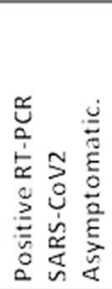 & 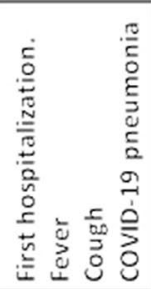 & 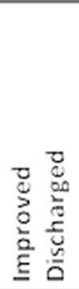 & 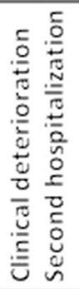 & 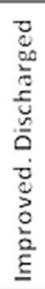 & 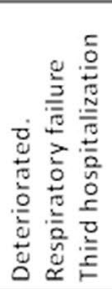 & 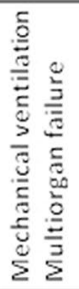 & 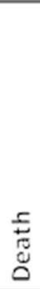 \\
\hline
\end{tabular}

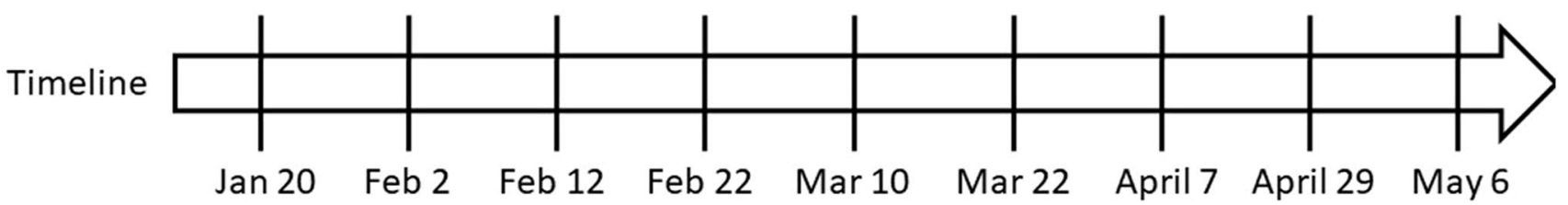

Fig. 2 Timeline of disease course 
Table 1 Studies reporting patients with systemic rheumatic diseases under RTX treatment who developed an atypical and/or protracted course of SARS-CoV-2 infection

\begin{tabular}{|c|c|c|c|c|}
\hline Reference & $\begin{array}{l}\text { Type of systemic } \\
\text { rheumatic disease } \\
\text { (sex/age) }\end{array}$ & Severity of COVID-19 & $\begin{array}{l}\text { Treatment (apart from } \\
\text { steroids)-Outcome }\end{array}$ & Comments \\
\hline Aviv et al. & RA (F/50) & $\begin{array}{l}\text { Initially mild symptoms that } \\
\text { persisted. Later she devel- } \\
\text { oped relapsing COVID-19 } \\
\text { pneumonia }\end{array}$ & $\begin{array}{l}\text { IVIG, remdesivir and } \mathrm{CP} \\
\text { Fully recovered }\end{array}$ & $\begin{array}{l}\text { Hypoglobulinemia } \\
\text { Absence of anti-SARS-CoV-2 } \\
\text { antibodies }\end{array}$ \\
\hline Guilpain et al. & GPA $(F / 52)$ & $\begin{array}{r}\text { Severe disease requiring } \\
\text { mechanical ventilation }\end{array}$ & $\begin{array}{l}\text { Lopinavir/ritonavir and HCQ } \\
\text { Fully recovered on day \#29 }\end{array}$ & $\begin{array}{l}\text { RTX was administered a day } \\
\text { prior to COVID-19 diagnosis. } \\
\text { The patient was also on } 15 \mathrm{mg} \\
\text { prednisone when infected }\end{array}$ \\
\hline Friedman et al. & GPA $(F / 30)$ & $\begin{array}{l}\text { Initial mild disease that } \\
\text { resolved completely but } \\
\text { a month later developed } \\
\text { COVID-19 pneumonia }\end{array}$ & $\begin{array}{l}\text { Banlanivimab } \\
\text { Fully recovered within weeks }\end{array}$ & $\begin{array}{l}\text { Absence of anti-SARS-CoV-2 } \\
\text { antibodies }\end{array}$ \\
\hline Benucci et al. & Polymyositis (F/60) & $\begin{array}{l}\text { Severe pneumonia requiring } \\
\text { mechanical ventilation }\end{array}$ & $\begin{array}{l}\text { Remdesivir, } \mathrm{CP} \text {, tocilizumab } \\
\text { and IVIG } \\
\text { Full recovery }\end{array}$ & $\begin{array}{l}\text { Absence of anti-SARS-CoV-2 } \\
\text { antibodies }\end{array}$ \\
\hline Quartuccio et al. & GPA $(F / 73)$ & $\begin{array}{l}\text { Severe pneumonia leading to } \\
\text { respiratory failure }\end{array}$ & Died on day \#25 & $\begin{array}{l}\text { Absence of anti-SARS-CoV-2 } \\
\text { antibodies. Low total IgG } \\
\text { levels }\end{array}$ \\
\hline Leipe et al. & GPA (M/63) & $\begin{array}{l}\text { Atypical symptoms with initial } \\
\text { mild pneumonia that gradu- } \\
\text { ally deteriorated requiring } \\
\text { oxygen supplementation }\end{array}$ & Recovered on day \#32 & $\begin{array}{l}\text { RTX was administered } 2 \text { weeks } \\
\text { before COVID-19 }\end{array}$ \\
\hline Gerber et al. & RA (M/46) & $\begin{array}{l}\text { Pneumonia requiring oxygen } \\
\text { supplementation }\end{array}$ & $\begin{array}{l}\text { Remdesivir and CP } \\
\text { Fully recovered on day \#56 }\end{array}$ & $\begin{array}{l}\text { Absence of anti-SARS-CoV-2 } \\
\text { antibodies }\end{array}$ \\
\hline Kenig et al. & $\begin{array}{l}\text { 1. GPA (M/45) } \\
\text { 2. RA (F/64) }\end{array}$ & $\begin{array}{l}\text { 1. Protracted pneumonia } \\
\text { 2. Severe pneumonia requiring } \\
\text { oxygen supplementation }\end{array}$ & $\begin{array}{l}\text { 1. Dramatic response to } \mathrm{CP} \\
\text { administered on day \#50 } \\
\text { 2. Improved } 10 \text { days following } \\
\mathrm{CP}\end{array}$ & \\
\hline Daniel et al. & GPA (M/55) & Protracted pneumonia & $\begin{array}{l}\mathrm{HCQ} \text {, lopinavir/ritonavir } \\
\text { Full recovery but persistent } \\
\text { viral shedding for } 2 \text { months }\end{array}$ & $\begin{array}{l}\text { Absence of anti-SARS-CoV-2 } \\
\text { antibodies }\end{array}$ \\
\hline Koff et al. & GPA $(F / 71)$ & $\begin{array}{l}\text { First symptoms on day \#21 } \\
\text { following positive PCR. } \\
\text { Developed pneumonia on day } \\
\text { \#36 }\end{array}$ & Full recovery & $\begin{array}{l}\text { Hypoglobulinemia } \\
\text { Absence of anti-SARS-CoV-2 } \\
\text { antibodies }\end{array}$ \\
\hline Schulze-Koops et al. & $\begin{array}{l}\text { 1. RA (M/71) } \\
\text { 2. RA (F/80) }\end{array}$ & $\begin{array}{l}\text { 1. Severe pneumonia leading } \\
\text { to multiorgan failure } \\
\text { 2. Severe pneumonia leading } \\
\text { to multiorgan failure }\end{array}$ & $\begin{array}{l}\text { 1. Died on day } \# 12 \\
\text { 2. Died on day \#17 }\end{array}$ & Both had normal IgG levels \\
\hline Avouac et al. & $\begin{array}{l}\text { 1. SSc }(\mathrm{M} / 71) \\
\text { 2. SSc }(\mathrm{F} / 84) \\
\text { 3. SSc }(\mathrm{F} / 44)\end{array}$ & $\begin{array}{l}\text { Initial mild symptoms. } \\
\text { Deteriorated on days \#19,\#15 } \\
\text { and \#23 respectively }\end{array}$ & $\begin{array}{l}\text { 2. Anakinra, Tocilizumab } \\
\text { All patients recovered }\end{array}$ & $\begin{array}{l}\text { None had interstitial lung } \\
\text { disease }\end{array}$ \\
\hline Vasconcelos et al. & RA $(F / 43)$ & Protracted pneumonia & $\begin{array}{l}\text { Dramatic response to IVIG } \\
\text { Fully recovered on day \#32 }\end{array}$ & $\begin{array}{l}\text { Hypoglobulinemia } \\
\text { Absence of anti-SARS-CoV-2 } \\
\text { antibodies }\end{array}$ \\
\hline Rodriguez-Pla et al. & GPA (M/77) & Prolonged course & $\mathrm{CP}$ & $\begin{array}{l}\text { Absence of anti-SARS-CoV-2 } \\
\text { antibodies }\end{array}$ \\
\hline
\end{tabular}

$C P$ convalescent plasma, GPA granulomatosis with polyangiitis, $R A$ rheumatoid arthritis, $I V I G$ intravenous immunoglobulin, $H C Q$ hydroxychroroquine, SSc Systemic sclerosis

\section{Discussion}

Our case indicates that RTX may unfavorably affect outcomes following SARS-CoV-2 infection. B cell depletion may dampen the humoral response against the virus; we may hypothesize that B cell-depleted patients may be 
protected from cytokine storm but on the other hand may have difficulties in virus clearance leading to a protracted course. Taking into account that COVID-19 vaccines are available we may consider delaying RTX infusions at least in patients without life-threatening disease, until vaccination is completed.

\section{References}

1. Strangfeld A, Schäfer M, Gianfrancesco MA, Lawson-Tovey S, Liew JW, Ljung L et al (2021) Factors associated with COVID19-related death in people with rheumatic diseases: results from the COVID-19 Global Rheumatology Alliance physician-reported registry. Ann Rheum Dis 80(7):930-942

2. Bakasis A-D, Mavragani CP, Boki KA, Tzioufas AG, Vlachoyiannopoulos PG, Stergiou IE et al (2021) COVID-19 infection among autoimmune rheumatic disease patients: data from an observational study and literature review. J Autoimmun 123:102687

3. Avouac J, Drumez E, Hachulla E, Seror R, Georgin-Lavialle S, El Mahou S et al (2021) COVID-19 outcomes in patients with inflammatory rheumatic and musculoskeletal diseases treated with rituximab: a cohort study. Lancet Rheumatol 3(6):e419-e426

4. Spelman T, Forsberg L, McKay K, Glaser A, Hillert J (2021) Increased rate of hospitalisation for COVID-19 among rituximabtreated multiple sclerosis patients: a study of the Swedish multiple sclerosis registry. Mult Scler J 2:135245852110262

5. Tani C, Carli L, Vagnani S, Talarico R, Baldini C, Mosca M et al (2014) The diagnosis and classification of mixed connective tissue disease. J Autoimmun 48-49:46-49

6. Aviv R, Weber A, Anzum T, Federbush M, Horowitz D, Singas E (2021) Prolonged COVID-19 disease in a patient with rheumatoid arthritis on rituximab therapy. J Infect Dis 224(3):557-559. https://doi.org/10.1093/infdis/jiab248

7. Guilpain P, Le Bihan C, Foulongne V, Taourel P, Pansu N, Maria ATJ et al (2021) Rituximab for granulomatosis with polyangiitis in the pandemic of covid-19: lessons from a case with severe pneumonia. Ann Rheum Dis 80:E10 (BMJ Publishing Group)

8. Friedman MA, Winthrop KL (2021) Second COVID-19 infection in a patient with granulomatosis with polyangiitis on rituximab. Ann Rheum Dis. (BMJ Publishing Group)

9. Benucci M, Quartuccio L, Li Gobbi F, Damiani A, Grossi V, Infantino $\mathrm{M}$ et al (2020) Persistence of rT-PCR-SARS-CoV-2 infection and delayed serological response, as a possible effect of rituximab according to the hypothesis of Schulze-Koops et al. Ann Rheum Dis https://doi.org/10.1136/annrheumdis-2020-218590. (BMJ Publishing Group)

10. Quartuccio L, Treppo E, Binutti M, Del Frate G, De Vita S (2021) Timing of rituximab and immunoglobulin level influence the risk of death for COVID-19 in ANCA-associated vasculitis. Rheumatology 20(34):185-191

11. Leipe J, Wilke EL, Ebert MP, Teufel A, Reindl W (2020) Long, relapsing, and atypical symptomatic course of COVID-19 in a B-cell-depleted patient after rituximab. Semin Arthr Rheum 50:1087-1088 (W.B. Saunders)

12. Gerber V, Velay A, Boehn L, Solis M, Kaeuffer C, Rougier E et al (2021) Protracted SARS-CoV-2 pneumonia with rituximab treatment: about two cases. J Med Virol 93:4141-4144. (John Wiley and Sons Inc.)

13. Kenig A, Ishay Y, Kharouf F, Rubin L (2021) Treatment of B-cell depleted COVID-19 patients with convalescent plasma and plasma-based products. Clin Immunol 227:108723

14. Daniel P, Raad M, Waked R, Choucair J, Riachy M, Haddad F (2020) COVID-19 in a patient treated for granulomatosis with polyangiitis: persistent viral shedding with no cytokine storm. Eur J Case Rep Intern Med 7(10):001922

15. Koff A, Laurent-Rolle M, Hsu JCC, Malinis M (2020) Prolonged incubation of SARS-CoV-2 in a patient on rituximab therapy. Infect Control Hosp Epidemiol 1-2. https://doi.org/10.1017/ice. 2020.1239. (Online ahead of print)

16. Schulze-Koops H, Krueger K, Vallbracht I, Hasseli R, Skapenko A (2021) Increased risk for severe COVID-19 in patients with inflammatory rheumatic diseases treated with rituximab. Ann Rheum Dis 80:e67 (BMJ Publishing Group)

17. Avouac J, Airó P, Carlier N, Matucci-Cerinic M, Allanore Y (2021) Severe COVID-19-associated pneumonia in 3 patients with systemic sclerosis treated with rituximab. Ann Rheum Dis 80:37 (BMJ Publishing Group)

18. Vasconcelos J, Portugal R, Torres R, Falcão S (2021) Intravenous immunoglobulin as a therapeutic option for patients with worsening COVID-19 under rituximab. BMJ Case Rep 14(6):e243338

19. Rodriguez-Pla A, Vikram HR, Khalid V, Wesselius LJ (2021) COVID-19 pneumonia in a patient with granulomatosis with polyangiitis on rituximab: case-based review. Rheumatol Int 41(8):1509-1514

Publisher's Note Springer Nature remains neutral with regard to jurisdictional claims in published maps and institutional affiliations. 